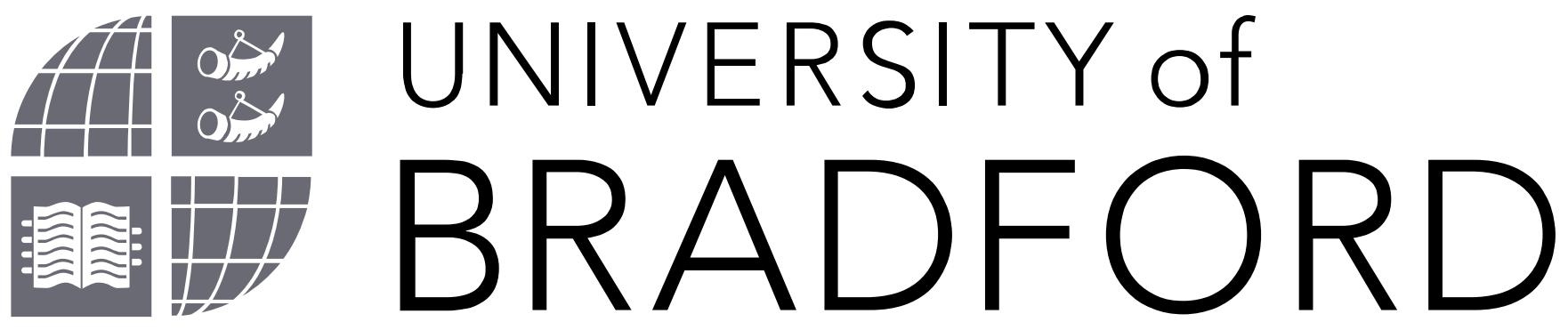

Should I stay or should I go now? Exploring Polish women's returns "home"

\begin{tabular}{|l|l|}
\hline Item Type & Article \\
\hline Authors & Duda-Mikulin, Eva A. \\
\hline Citation & $\begin{array}{l}\text { Duda-Mikulin EA (2018) Should I stay or should I go now? } \\
\text { Exploring Polish women's returns “home”. International } \\
\text { Migration. 56(4): 140-153. }\end{array}$ \\
\hline Download date & 27/07/2018 11:46:30 \\
\hline Link to Item & http://hdl.handle.net/10454/14546 \\
\hline
\end{tabular}




\section{The University of Bradford Institutional Repository}

http://bradscholars.brad.ac.uk

This work is made available online in accordance with publisher policies. Please refer to the repository record for this item and our Policy Document available from the repository home page for further information.

To see the final version of this work please visit the publisher's website. Access to the published online version may require a subscription.

Link to publisher version: https://doi.org/10.1111/imig.12420

Citation: Duda-Mikulin EA (2018) Should I stay or should I go now? Exploring Polish women's returns "home". International Migration. Accepted for publication.

Copyright statement: (c) The Author and International Migration. Full-text reproduced with author permission and in accordance with the publisher's self-archiving policy. 


\title{
Should I stay or should I go now? Exploring Polish women's returns "home"
}

\author{
Eva A. Duda-Mikulin
}

\begin{abstract}
At a time when there are more people on the move than ever before, it is pivotal to explore people's motivations and experiences of return migration. Whilst motivations for migration are comparatively well explored, return migrants' experiences are less well-known and migrants' gender is rarely considered. This article addresses these gaps. It is based on qualitative research and in-depth interviews with 32 Polish women: 16 migrants and 16 return migrants. Considered through the lens of agency and structure, this research uncovers how fluid the process of migration has become; migration motivations and patterns are blurred and interlinked with one another while classic migration theories seem outdated. The study uses an "intersection of motivations" to show how inseparable migration-related motivations have become. This article contributes to the growing literature on East-West return migration and highlights women as migrants and the gendered nature of their mobility.
\end{abstract}

\section{INTRODUCTION}

There are more people on the move than ever before. Around 3.3 per cent of the world's population (approximately 244 million people) live in a country that is not their country of origin (UN, 2015). In 2013, the United Kingdom (UK) was home to approximately 7.8 million international migrants, which made it the fifth most attractive destination country in the world (OECDUNDESA, 2013). Following the expansion of the European Union (EU) in 2004 migration from Accession 8 (A8/EU8) ${ }^{1}$ to the UK was identified as one of the most significant social phenomena (Pollard et al., 2008). Polish nationals migrating to the UK after 2004 were the largest migrant community, from Central and Eastern European (CEE) countries which joined the EU in 2004 (Trevena, 2009; Drinkwater \& Garapich, 2015). Later on, Polish migrants became a vibrant and growing community in the UK (Isański \& Luczys, 2011). The economic migrant argument has been applied to Polish migrants to the UK, the majority of whom have been identified as such (Irek, 2011). While some sources claim that large numbers of A8 workers have left the country in the aftermath of the global economic crisis in 2008 (Pollard, 2008); others acknowledge a constant circulation of migrants between the UK and their homeland in order to access work. Additionally, substantial numbers appear to be long-term residents settled in the UK (White, 2014).

It has been widely accepted that migration is gendered (Pessar \& Mahler, 2003; Yeoh \& Ramdas 2014). Morokvasic $(1983,13)$ argues that although women play a crucial role in migration, they have been "sociologically invisible, although numerically and socially present" and that the presence of women was finally acknowledged when they entered the waged labour market. The assumptions of a male breadwinner family model and traditional gender roles have dominated 
classic migration theories (Ackers, 1998). This article contributes to return migration literature illuminating women as migrants. It brings women's experiences of migrating to the fore, and thus provides more balance in migration literature. It presents new and unique evidence concerning women's return migrations. Previous studies (Snel et al. 2015) theorised motivations for return migration; this article is based on empirical research on return migrants, which is an understudied area (Parutis, 2014). In this article, women migrants' accounts are presented, in response to the male bias prevalent in international migration literature (Lutz, 2010) and the call for more research on women migrants (Eaves, 2015). Although the focus is on moves between Poland and the UK, this article has wider implications for East-West mobility and transnational migration more generally.

This article focuses on women's post 2004 international migratory flows between Poland and the UK, two Member States of the EU. ${ }^{2}$ During this period, the UK remained an attractive destination for economic migrants due to a relatively low unemployment rate, labour shortages and comparatively high economic performance, particularly in relation to CEE countries (Trevena, 2009). Polish migrants represent a distinctive case of large-scale economic migration to the UK enacted within new institutional settings of intra-European migration. The article addresses the following questions: why do women (decide to) return to the "home" country following an initial emigration? What impact, if any, does gender have on women's return migrations?

This article emphasises a discrepancy between the image of an economic migrant in theory, practice and popular debates and the experiences of women migrants. It highlights women as migrants in their own right with various gendered responsibilities that often migrate with them. First, the theoretical context is outlined with particular attention paid to structure and agency, gender in migration and return migration. This is followed by a section on methods of data collection. The analysis section explores three wide themes: "unintentional unpredictability", women's sense of belonging and family as their frame of reference. The last part of this article includes concluding remarks and policy implications.

\section{THEORETICAL CONTEXT}

\section{Structure and agency in migration}

Structure and agency have long been considered vital to explaining human behaviour (Giddens, 1984) and key to debates around migration (Morawska, 2001; Hoang, 2011). According to Giddens (1984), both concepts can serve as enabling and constraining factors all at the same time. Agency can be understood as "the capacity for social actors to reflect on their position, devise strategies and take action to achieve their desires" (Bakewell, 2010, p.1694). While, "structures [are] conceived of as patterns of social (including economic and political) relations and cultural formations constituted through everyday practice of social actors" (Morawska, 2001, p.52). Migrating involves a complex interaction of certain structures that both foster and inhibit people's movements as active agents (Bakewell, 2010).

Certain structural opportunities and constraints frame the agency of Polish women migrants to the UK. These are related to the government policy and the welfare state in both Poland and the UK. That EU citizenship facilitated the recent "wave" of Polish migration is also part of the structural context. Additionally, cultural norms in relation to gender roles are part of the structural setting. Social networks can also be considered as structures and the context and composition of migrants' networks affect their motives to remain or return "home" (Ryan, 2009). Whilst "bonding" can make them attached to a particular migrant community, "bridging" may influence their decision to stay as it increases the feelings of being at home (Nannestad, Svendsen \& Svendsen, 2008). 
Arguably, unless migrants are bridging human capital, and develop meaningful relationships with the host population, they will not feel settled so are likely to return. Research has documented that Polish migrants to the UK realise the value of having British friends (Scullion \& Pemberton, 2010). Additionally, migrants' social networks and families could be anchors or magnets and push/ pull them accordingly (Ryan, 2009).

The abovementioned factors are gendered and can act as limitations to exercising agency (e.g. the relatively limited Polish welfare state) but they can also serve as opportunities (e.g. the comparatively more generous British welfare system). Thus, structure constitutes opportunities and/or constrains while agency is facilitated and/or circumscribed by structure and social actors continuously engage in a renegotiation of these. Although the expanded EU may present a structural context that enables migration for EU citizens, European citizenship remains a "highly stratified status" (Dwyer, 2004) which offers preferential rights to economically active migrants as the original goal of the EU was to promote and facilitate the movement of workers. The majority of recent Polish nationals in the UK are economic migrants, thus their movement has been relatively unobstructed; although their welfare rights have been curtailed at different points in recent years (Pemberton \& Scullion, 2013).

\section{Gender in migration}

Female migrants began to appear in the literature from the mid-1970s; previously they were often portrayed as "followers, dependants, unproductive persons, isolated, illiterate and ignorant" (Morokvasic, 1983, 16). More recent studies consider women to be active decision-makers (Kindler \& Napierała, 2010). This dominant economic model of migration, male breadwinning and profitmaximising, evident in academic literature is under scrutiny here. This article focuses on women in migration as breadwinners, caregivers and free mobile agents.

A male bias in migration theory and literature is still evident (Morokvasic, 1983; Lutz, 2010; Yeoh \& Ramdas, 2014). Migrants are often portrayed as male, single and unburdened by a host of gendered responsibilities that have been traditionally and stereotypically assigned to women (Boyd \& Grieco, 2003; Temple, 2011). Even when a migrant has a family, he (as often asserted) is repeatedly represented as a migrant in his own right, a pioneer (Zlotnik, 2003), whilst his female partner is frequently depicted as a "tied mover" or a "trailing wife" (Cooke, 2001). In this article, internationally mobile women are considered as agents and represented as such.

The number of women who relocate internationally is on the increase. Worldwide, approximately 48 per cent of all migrants are women (UN, 2015); and "over the past thirty years, more females than males migrated to the UK" (Vertovec, 2007, 1040). Thus, some scholars emphasise the contemporary feminisation of migration ${ }^{3}$ (Castles \& Miller, 2009), while others argue this has been evident since the 1970s (Zlotnik, 2003). More than half of foreign-born migrant workers are women and within Europe women constitute 51 per cent of migrants (Rienzo, 2016). Although the majority of post-accession migrants are young male adults (UKBA, 2009), it is important to explore women from $\mathrm{A} 8$ countries and add to the literature on international women migrants.

In this article a gendered approach to theorisation was adopted. Gender ${ }^{4}$ is understood as a social construct and an important "force shaping human life" which has been "regularly sidelined in research on international migration" (Pessar \& Mahler, 2003, 812). Gender is linked to certain characteristics and expectations of women (and men) in any given society (Oakley 1972), and it may be employed, as here, as a key category in understanding migratory processes (Lutz, 2010).

\section{Return migration}

Issues around definition and mutually agreed factors that allow for the identification of return migrants are problematic (Parutis, 2014). In the 1970s and 1980s, return migration literature largely 
dealt with the consequences of return migration for migrants and for countries to which they were returning. In contemporary literature, the focus was shifted onto the destination country (Fihel \& Górny, 2013). This change denotes a shift of interest towards an exploration of determinants of returns and attempts to differentiate between definitive returns and circular migration (Dustman \& Weiss, 2007). Traditional definitions of return migration implied a fair amount of permanence; migration, however, is increasingly recognised as a process rather than a one-off event (Ackers, 2013) and such permanency can no longer be assumed (Dustman \& Weiss, 2007). Therefore it is difficult to distinguish return migrants from circular migrants or transmigrants. The distinction between 'migration' and 'mobility' suggests further complications in separating (return) migrants from mobile individuals (Faist, 2013). For the abovementioned reasons, traditional migration theories may no longer be applicable as they were developed when cross-border movements ware less fluid, less frequent and more difficult to pursue. After 2004, we observe less fixed migration patterns (Snel et al., 2015) and thus, an intersection of previously developed theories (e.g. neoclassical theory, new economics theory, worlds systems theory, network theory, see Massey et al., 1993) and an "intersection of motivations" may be more appropriate to explain this phenomenon.

Return migrants may be agents of innovation (Fihel \& Górny, 2013) but a return could be problematic as new norms may be destabilising and lead to "double marginalisation" whereby migrants do not feel part of either 'home' or host country (Iglicka, 2010). "Migration-specific capital" (Vertovec, 2007) presents the experience of migration as beneficial to migrants who wish to undertake subsequent migrations. Cerase's (1974) typology of returns needs a mention (i.e. returns of failure, returns of conservatism, returns of retirements and returns of innovation) and it could be asserted that all of those were, at some point, observed in relation to Polish migrants. To this typology, other types can be added: returns to explore undertaken prior to a permanent return (Iglicka, 2010) and incomplete returns whereby migrants have dual location households in both home and host countries (Iglicka, 2002).

Several different phases of return migration to Poland can be identified. The first one is linked to the economic emigration to the United States of America (USA) between 1919 and 1938 and their returns. The next phase is associated with the communist reign (1945-1989) and the mostly illegal emigration and return migration. The following phase relates to those who emigrated post 1990 and subsequently decided to return (Klagge et al., 2007). Fihel and Górny (2013) identified two separate waves of return migration from 1980s onwards. The first one occurred in the 1990s, immediately after the transition from communism to a market economy, and comprised mostly those who had previously emigrated to escape the communist system. The second wave of returnees consisted of those who, having emigrated post EU enlargement in 2004, later returned to Poland. According to estimates, the post-accession returns accounted for over half a million and were particularly noticeable after the global economic crisis of 2008 which stimulated moves back. (Fihel \& Górny, 2013). Okólski (2011) postulates that generally, research has shown positive effects of return migration to Poland, others however oppose such views (Iglicka, 2010). Research has shown that labour migrants from the EU are often goal-orientated and once that is met they return "home" ("hamsters", Eade et al., 2007). Still, migrant networks may anchor them in their host country but could also act as magnets and pull them back (Ryan, 2009). This may relate to women migrants more than male migrants as they tend to develop closer family ties.

Iglicka $(2010,39)$ found the following motives leading migrants to undertake returns: lack of work in the home country; no complex regulations preventing back and forth mobility; inexpensive cost of travel; limited social entitlements in the host country; migrant-specific employment; relatively short stay abroad; and lack of language proficiency. Anwar (1979) coined a "myth of return" which relates to migrants expressing a desire to return to their homeland at some point in the future; however, this often takes the form of a symbolic dream rather than actual plans to go back. White (2011) argues that for some Polish migrants to the UK, migration became a "livelihood strategy", and refers to "migration culture" in regard to specific places in Poland where people see 
migration as a way of life. For others, migration may be a way "to have fun and enjoy life before going back to the normal life and a normal family in Poland" (Cieślik, 2012, 15).

It is recognised that life-course stage (Cieślik, 2012) and gender influence migration-related decisions (Lawthom \& Kagan, 2016). Research indicates that married women migrants have less decision-making power than unmarried women, for instance Hoang (2011). Most of the post-accession migrants were at the beginning of their adult lives and thus relationship formation would have affected their migration plans. Many came to the UK to gain transferable experience that could later be utilised anywhere they may subsequently decide to move. Szewczyk (2012) termed this "brain training"; Bielewska (2011) named it "fluid migration", which is characterized by no settlement goal and no specified period of time, while Drinkwater et al. (2006) coined "intentional unpredictability" as characteristic of post-2004 CEE migrants.

\section{METHODS}

This article offers important insights that are of wider relevance to all those interested in developing a more in-depth understanding of women migrants' motivations to return to the home country and of the experiences of CEE migrants within the UK. For the purpose of this study, a migrant is understood as someone who has been resident in a country other than their country of origin for a minimum of six months; a return migrant is defined as someone who identifies themselves as such due to returning to their home country having spent some time (min. six months) abroad.

A qualitative approach to data was used. The fieldwork took place between October 2012 and February 2013. Strategic purposive sampling was utilised, with some snowballing. Most of the participants were recruited through existing networks in the voluntary community sector. Semi-structured interviews were the chosen research methods. 32 participants were interviewed, 16 migrants in the UK and 16 return migrants in Poland (for sample characteristics see Tables 1 and 2). All interviews were audio recorded for the purpose of verbatim transcription and took place in a range of venues including respondents' homes and cafes. Six Skype interviews were also carried out with those in more remote locations. As a token of appreciation for their time, each interviewee was given $£ 10$ upon completion of an interview (Duda-Mikulin, 2014).

The data were thematically analysed by systematic reading of the transcripts followed by their organisation into categories of preliminary codes (Braun \& Clarke 2006). Through constant comparison, a number of themes were identified, among them motivations to remain and reasons for return migration which correspond to the next two sections. The researcher was guided by a number of ethical principles, namely: respecting the dignity, rights, welfare and safety of research participants; ensuring informed consent and voluntary participation; protecting anonymity; ${ }^{5}$ and doing no harm (Olsen, 2012). The study was subject to institutional ethical approval.

\section{DISCOURSES OF RETURN MIGRATION}

I have provided a review of the literature relevant to the themes under exploration and explained the methodology. I will now discuss the empirical findings.

\section{Unintentional unpredictability: "It all depends. . for now I'm here”}

Among the reasons why Polish women migrants in this study did not return to their country of origin were: putting down roots (e.g. finding a partner); social and familiar networks; a pre-defined goal which has not been realised (e.g. saving up); and uncertainty (e.g. about the situation back 
"home"). This study confirms that the impact of migrants' social or family networks is still significant (Boyd, 1989). Indeed, the wider networks have facilitated many women's moves to the UK and in many cases seem to contribute to their prolonged stay. Many interviewees, over time, developed further links with the host country, e.g. found a partner, got married, and/or had children. Research (Łobodzińska, 2000; Temple, 2011) highlights that the majority of Polish nationals are Roman Catholics; many regularly attend church services and believe in family values, which offers some explanation as to why familial networks play a key part in migration decision-making. With time, migrants become increasingly attached to their host country which makes returns more problematic. Some participants established relationships with British partners, which is not uncommon especially for Polish women (Janta, 2013). Similarly to other studies' findings (Parutis, 2014), those women who had children in the UK wished to raise them near their families in Poland but believed they will not be able to secure as high standard of living as they enjoyed in the UK. Some migrants expressed their fears that children raised in the UK will not possess the same cultural heritage as those brought up in Poland.

Migrants' life stage (Ryan et al., 2009) and gender (Lawthom \& Kagan, 2016) are vital here. The majority of Polish migrants in the UK are "at a stage of their lives where people form relationships and have children" (Trevena, 2009, 13) which will inevitably affect their length of stay in the UK. It is perhaps difficult to make plans for the future when one is waiting to see how things will pan out. This illuminates the fluidity and open-ended nature of migration patterns and processes but also the precarity of migrants' lives which are characterised by uncertainty (Standing, 2011). The below account illustrates the way many women explained their plans for the future.

JULIA: we're [she and partner] going to stay permanently ... I mean for a few years and we'll see what will happen then...

Many Polish migrants demonstrate "unintentional unpredictability" and admit to having doubts about the future which seems to depend on the wider socio-economic situation in both countries. "Unintentional unpredictability" is in contrast to "intentional unpredictability" coined by Drinkwater et al. (2006) which highlights that Polish migrants to the UK often purposefully do not specify how long they may stay in the host country. In regard to the research participants, the unpredictability of their situation appears to be more often unintended. This could be explained by their socio-economic position which is characterised by precarity with regards to work and citizenship which is in support of other studies (Lawthom \& Kagan, 2016). No single reason behind the research participants' decisions to return to their homeland could be identified. In most cases an "intersection of motivations" was evident, which signifies that this process is not as neat as once thought.

\section{Sense of belonging: "You can never feel at home when you're abroad"}

Among the reasons for women's return migration were: social networks; difficulties adjusting (e.g. cultural differences); gendered expectations; and accomplishment of goals. One of the interviewed women, Magda, noted: "you can never feel at home when you're abroad". This statement emphasises the respondent's limited level of integration and community cohesion and reflects their sense of belonging and plans for the future. Relationships matter when it comes to the feeling of fitting in. Those who develop meaningful relationships with a wider group of people are more likely to remain. More of the migrants (as opposed to return migrants) talked about meaningful associations with British people (e.g. friendships; interactions with neighbours and colleagues). This may be an illustration of the return migrants' unwillingness to invest themselves (e.g. engage with local community; reach out for better jobs), hence their disinterest in developing those connections, which consequently influences their plans to return while they are focused on reaching their goal. Indeed, 
those who came with a clear goal (e.g. saving up; studies) seemed to think it would only be a matter of time after having achieved it that they would return to Poland. Those migrants could be compared to Eade et al.'s (2007) "hamsters", although their stays were not necessarily short-term or money-orientated.

Many women migrants who migrated at a young age (see Tables 1 and 2, particularly Table 2), which is common, never attempted to seek and/or secure work in Poland, hence their adult life began in the UK (Trevena, 2009). Therefore, it is likely they would experience difficulties with reintegration in a society that once was their home. Most probably the country has undergone changes while they were away, and they themselves somewhat changed through the experience of migration. Those who lost links and contacts in Poland, could be 'trapped' in the UK. Despite their lack of integration in the UK, they may not feel they belong in Poland either. Due to "double marginalisation" (Iglicka, 2010), they do not fit neatly in either of the two countries and thus their opportunities are limited. ${ }^{6}$

This research shows more fluid patterns of migration or "liquid forms of migration" to quote Drinkwater and Garapich (2015). Whilst migration theories appear to still be relevant, the study participants have shown a diverse range of intersecting motives that do not neatly fall under one theory; less fixed patterns are evident. Therefore, an "intersection of motivations" (e.g. economic reasons + social networks) is useful in explaining migrants' motives which exposes multiple (return) migration motivations and is characteristic of this research cohort. This may be the case with regards to most (if not all) contemporary international migrants who can now move more easily which fosters more frequent migrations; thus, migration-related motivations are more varied and multiple.

Several interviewees explained that their return was due to various cultural differences that they perceived as unwelcome, they undertook "returns of conservatism" (Cerase, 1974). In those cases, migrants left the UK as they could not (or did not wish to) adjust to the differences in culture and language between the two countries. Consequently, this impeded their integration and the possibility of permanent settlement. Lena, quoted below, was unhappy about the fact that she could not utilise her skills and qualifications as she experienced de-skilling and "brain waste" which is not uncommon among migrants (Iglicka, 2010). Despite being relatively well educated, she found herself in low-paid, low-skilled work.

LENA: We [Lena and partner] got back because I just couldn't adjust there. We went to a crappy place, an industrial town. And work there was mainly in factories, it was difficult to find anything else. That's one thing; another was the language (...) And that was difficult for me, to switch, because you learn [English] at school for so long and go there [UK] and it turns out it's no use anyway (...) That surprised me and that those people, there's this mentality, so simple... No one there goes to university. Everyone focuses on work and earning and partying at the weekend.

Lena's account also points to discrepancies in socio-economic status of her place of origin and destination. Those migrants whose destination place does not match their place of origin (e.g. town - city) may feel they can never belong there. The return migrant women, on average, had higher levels of education than the migrant women from the sample and often returned in order to better utilise their skills in their country of origin. While some migrants may experience "double marginalisation", others may fall into a "migration trap" and continue to pursue further migrations. Indeed, some of the interviewees admitted they were planning or had considered further migrations perhaps due to accumulating "migration-specific capital" (Vertovec, 2007).

\section{Family as women's frame of reference: "It's unfair on your family to move abroad"}

Some very gendered motivations for return migration were uncovered - the need to provide or receive care and following a partner. Polish migrant women from this study often returned as a 
result of the pressure brought to bear on them as women. It could be said that their gender role expectations acted as structural constraints on their agency. One of the participants, Anna, remarked: "it's unfair on your family to move abroad" which signifies that Anna's family is her frame of reference. Hoang (2011) reported similar findings in relation to Vietnamese migrants. Gendered expectations affect women's plans for the future. The need to provide or receive care to or from family in Poland was one of the reasons for return. Many women experienced what Ryan et al. (2009) termed "double caring responsibilities" which cross international borders and come from the home and host country. Many women migrants felt responsible for the families they left behind. This feeling is more negative than was reported in previous studies where it was seen as pragmatic and as a way to receive care too (Parutis, 2014). They often felt obligated to return eventually to provide care and support; hence considering family as "anchors" is relevant here (Ryan, 2009). In other cases, it was due to missing relatives and the desire to bring up children near their families which has an emotional value. In some instances, women returned in order to live closer to their families and be able to both receive and provide care if/when necessary. The care they often sought was linked to having their own children looked after whilst they engage in other activities. This way, they were able to avoid the cost of childcare in the UK and engage in paid work. At the same time, their children enjoyed more time with their relatives learning about the Polish culture and tradition.

MARTA: We planned to have a child and we were slowly planning our return to Poland. We wanted to take over my parents' business, a bar, shop, B\&B... One of the most important reasons that made us want to go back was that we wanted our child to grow up in a complete family, in this big, happy, multigenerational family. So that when we want to go out somewhere, then grandma steps in and looks after the child... It was this happy family idyll that I had in mind and this was one of the main reasons why we decided to leave everything here [UK], me work, my partner his job and chase our Polish dream [laughs].

Interestingly, women who did not have a family of their own were expected to provide care to their parents. This is a gendered expectation but further research is needed to be certain. It appears that these obligations are mostly felt by the women rather than implied by their families. This is in support of the "strong motherhood ideology" in Poland whereby women are predominantly seen as carers and motherhood is perceived as women's principal obligation (Lutz, 2010). However, having children cancels this gendered expectation in most cases but this is dependent on family composition (e.g. having siblings). Evidently, migrants' networks may act as facilitating and constraining forces, on the one hand fostering moves to the UK, and on the other encouraging a return to Poland.

Kornelia, quoted below, similarly to other participants, explained she will have to return at some point in order to provide care to her parents. Women like Kornelia put their own plans on hold as eventually they will be needed back in Poland. Here, familial networks prove to be "magnets" (Ryan, 2009). In some cases, the vision of having to go back was unwanted and somewhat disheartening as illustrated in Kornelia's account.

KORNELIA: I'd like to find someone and just live here [UK], stay here. But I'm worried about my parents because they live alone, they won't get any younger but older, and it's just that I worry about, because we actually have a big house in Poland, you need to burn wood, carry the coal. And it's just this one thing that worries me, because they will only get older. That's why my plans here that I want to stay here for good, this is what I want, but what will happen and what I will have to do, only time will tell.

Often, women migrants follow their gender roles in the way they act in household decision-making as was found by Hoang (2011). Gender roles are structures enabling and constraining individual agency (Lawthom \& Kagan, 2016). Consequently, women's traditional gender ideology prevalent in a patriarchal society (e.g. Poland; Łobodzińska, 2000) limits their agentic powers. 
Similarly to motivations for migration, some respondents followed their male counterparts in their return migration, thus classic migration theories are applicable (Massey et al., 1993). Some of the women noted they would be happy to remain but their partners did not feel as comfortable in the UK. This may point to a comparatively higher level of integration enjoyed by the women which could result from the different nature of their employment. Polish men to the UK tend to be concentrated in the construction sector and factory work whilst Polish women are more often employed in the service sector (Scullion \& Pemberton, 2010). This could create a disparity with regards to the level of English language proficiency and, in consequence, integration. Those working in the service sector have more contact with society at large thus practise their language skills more often. Whereas the construction sector and factory work do not require employees to engage in conversations as often (or, as a matter of fact, in English). ${ }^{7}$ Having outlined the research findings in relation to women migrants' rationale for return migration, the final section offers some concluding remarks and wider policy implications.

\section{CONCLUSION}

Classic migration theories have for long played a central part with regards to explaining migratory moves. However, current migration patterns call for revisiting earlier classifications of migrants and for new theories and concepts to be developed. This article aims to fill gaps in knowledge on return migration and, by focusing on women migrants, provide more balance in migration literature. The return migrants' motivations presented in this article are a unique contribution to migration studies literature and thus may have implications for other international women migrants.

Blurring of migration forms and patterns is apparent. It is argued that rigid migration theories are no longer applicable to contemporary migrations which are undertaken more flexibly, frequently and cheaply. While migrating became easier to pursue, traditional theories have become somewhat redundant as moving has become more fluid, circular, frequent and various intersecting motivations are more appropriate in explaining people's contemporary mobility. Hence, an "intersection of motivations" is relevant in relation to decisions to remain or go back "home". This concept emphasises a combination of factors that influence migrants as demonstrated by the respondents' decisions to remain or return to Poland. The findings from this research emphasise Polish migrant women's "unintentional unpredictability" with regards to future plans to remain in the host country or return to the home country. The migrants who expressed a desire to go back in the future, in most cases, were uncertain about when this might be or whether it would happen at all, thereby demonstrating "unintentional unpredictability".

Migration is a gendered process and migrants should not be portrayed as single males when half of them are women. This research confirmed that gender and social networks are pivotal in migration decision-making and can facilitate as well as impede migratory moves. Both gender and networks act as structures that influence women's agentic powers. They push and pull migrants with various strength and can stall women's plans to settle. Women's gendered roles and expectations pull them back to their country of origin where they are expected to undertake care work.

Financial (e.g. savings; remittances) and social (e.g. work/life experience; language skills; new ideas/identity) gains, consequences of migration, can add to the difficulty of reintegration since it is most probable that the home country has been transformed in migrants' absence; while the migrant is somewhat changed too. A migrant returning to her country of origin may no longer feel "at home" there. Consequently, a return migrant (rather than a returnee which would imply more permanence) has to balance their sometimes contradictory preconceptions with regard to their country of birth. Like any research, the presented study is not without its limitations. It provides a snapshot of the migrant population at a particular time and thus it cannot be taken as read that this applies to every migrant. 
This study emphasises the disparity between the image of an economic migrant in popular debates and the experiences of women migrants. There is a general lack of consideration for the needs of women migrants and rather gender-neutral immigration policies whereby migrants are often perceived as genderless workers without regard to gendered responsibilities they may hold. This research highlights the need to overcome this one-dimensional perception of economic migrants. It has shown that women migrants are often intertwined (or "sandwiched") in conflicting gendered expectations arising from two locations - the home and host countries. Thus, it should be acknowledged that economic migrants too, are entangled in multifaceted familial and other relationships that may make it more difficult for them to stay mobile or remain outside their country of origin. It is argued here that migration theorists should acknowledge women as migrants in their own right and consider their gendered "responsibilities" which may migrate with them.

Moreover, the British authorities should recognise the vital roles that migrants, and women migrants in particular, play in the British economy. The fiscal benefits of EU migrants have been considered elsewhere (Dustman \& Frattini, 2013); but it is also crucial to acknowledge migrant women's roles in "topping up" the birth and fertility rates; by doing so they contribute to the prevention of the ageing process (ONS, 2012). Further restrictions on welfare entitlements will likely impede this process, increasing the probability of a demographic crisis by accelerating its ageing process. On the other hand, the Polish authorities should recognise that the outflow of vast numbers of mostly young and well educated people is undoubtedly linked to their perception of Poland as a comparatively less attractive country and to the relatively limited support from the Polish state. Many of the interviewed women bluntly stated they would not start a family if they stayed in Poland as it does not provide a desirable environment. Thus, it could be asserted that more familyfriendly policies are needed. The importance of this should not be dismissed in light of Poland's decreasing birth and fertility rates (White, 2014).

\section{ACKNOWLEDGEMENTS}

This article is based on research funded by a Graduate Teaching Assistantship scholarship from the University of Salford. During this project, the researcher was awarded several external funding grants (research fellowship from the Jagiellonian Polish Research Centre in London, and the Fran Trust) and is grateful for this financial support. The author would like to thank Katherine Runswick-Cole and Rebecca Lawthom and the anonymous reviewers for their constructive comments on earlier versions of this article.

\section{NOTES}

1. EU8 - "new EU Member States which joined the EU on $1^{\text {st }}$ May 2004 (Czech Republic, Estonia, Hungary, Latvia, Lithuania, Poland, Slovakia, Slovenia)

2. Although, on the $23^{\text {rd }}$ June 2016 the UK voted to leave the EU and Article 50 was triggered on the $29^{\text {th }}$ March 2017, the process of Brexit will take some time and the UK is likely to remain part of the EU until early 2019 .

3. Some scholars (e.g. Castles \& Miller, 2009; Kilkey, Lutz \& Palenga-Möllenbeck, 2010; Lutz, 2011) note that female migrants are on the increase which is mainly due to women migrants undertaking domestic and/ or care work in economically more prosperous countries. Others, however, (e.g. Zlotnik, 2003), argue that the number of women migrants has been rising steadily since the 1970s. What has been named a "feminisation of migration" is nonetheless noteworthy as it brings attention to women migrants who are considered in this article.

4. Even though it is important to acknowledge that the concept of gender relates to both men and women, this article focuses solely on women. 
5. All of the participants' names used in this article are pseudonyms chosen by the interviewees themselves.

6. While this research is based on data with women migrants, some of the issues above concern both genders.

7. In certain factories Polish and/or other Central and Eastern European workers are so common that they can often communicate in their native language so that acquiring English language skills becomes unnecessary.

\section{REFERENCES}

Ackers, L.

1998 "Moving People and Knowledge: The Mobility of Scientists within the European Union", https:// www.liverpool.ac.uk/media/livacuk/ewc/docs/Ackers-paper03.2004.pdf (accessed 21 November 2017)

2013 "From 'Partial Migrations' to mundane transnationalism: Socio-legal (Re) conceptualisations of contemporary intra-EU migration", On-Line Journal on Free Movement of Workers within the EU, no 6 .

Anwar, M.

1979 The Myth of Return: Pakistanis in Britain. Heinemann Educational Books, London.

Bakewell, O.

2010 "Some reflections on dtructure and sgency in migration theory", Journal of Ethnic and Migration Studies, 36(10): 1689-1708. https://doi.org/10.1080/1369183X.2010.489382.

Bielewska, A.

2011 "National identities of Poles in Manchester: Modern and postmodern geographies", Ethnicities, 12: 86-105. https://doi.org/10.1177/1468796811427086.

Boyd, M.

1989 "Family and personal networks in international migration: Recent developments and new agendas", International Migration Review, 23(3): 638-670.

Boyd, M., and E. Grieco

2003 "Women and migration: Incorporating gender into international migration theory", Migration Information Source, http://www.migrationinformation.org/Feature/display.cfm?id=106 (accessed 21 November 2017)

Braun, V., and V. Clarke

2006 "Using thematic analysis in psychology", Qualitative Research in Psychology, 3: 77-101. https://d oi.org/10.1191/1478088706qp063oa.

Calkin, A.B.

2003 "The course of precision teaching", The European Journal of Behavior Analysis, 4: 87-96.

Castles, S., and M. Miller

2009 The Age of Migration. International Population Movements in the Modern World, (4 ${ }^{\text {th }}$ ed.). Palgrave Macmillan, Basingstoke.

Cerase, F.P.

1974 "Expectations and reality. A study of return migration from the United States to Southern Italy", Journal of International Migration Review, 8(2): 245-262.

Cieslik, A.

2012 Transnational mobility and family planning decisions. A case study of skilled Polish migrant women. MMG Working Paper 12-14 Max-Planck-Institut zur Erforschung multireligiöser und multiethnischer Gesellschaften, Max Planck Institute for the Study of Religious and Ethnic Diversity. Göttingen. http://www.mmg.mpg.de/fileadmin/user_upload/documents/wp/WP_12-14_Cieslik_Transna tional-mobility.pdf

Cooke, T.J.

2001 “'Trailing wife' or 'trailing mother'? The effect of parental status on the relationship between family migration and the labor-market participation of married women", Environment and Planning, 33: 419-430. https://doi.org/10.1068/a33140.

Drinkwater, S., and M. Garapich

2015 "Migration strategies of Polish migrants: Do they have any at all?", Journal of Ethnic and Migration Studies, 41(12): 1909-1931. 
Drinkwater, S.J., J. Eade and M. Garapich

2006 "Poles apart? EU enlargement and the labour market outcomes of immigrants in the UK", IZA Discussion Paper No. 2410. Bonn: The Institute for the Study of Labor.

Duda-Mikulin, E.A.

2014 "Interviewing Polish migrant women in the United Kingdom and Poland", InSAGE Research Methods Cases. SAGE Publications, Ltd., London, UK. https://doi.org/10.4135/ 978144627305014529524.

Dustman, C., and Y. Weiss

2007 "Return migration: Theory and empirical evidence from the UK", British Journal of Industrial Relations, 45(2): 236-256.

Dustman, C., and T. Frattini

2013 The Fiscal Effects of Immigration to the UK. Centre for Research and Analysis of Migration (CReAM). Discussion Paper Series, CDP No 22/13.

Dwyer, P.

2004 "Creeping conditionality in the UK: from welfare rights to conditional entitlements", Canadian Journal of Sociology, 29(2): 265-287. https://doi.org/10.1353/cjs.2004.0022.

Eade, J., S. Drinkwater, and M. Garapich

2007 "Class and ethnicity: Polish migrant workers in London", End of Award Research Report, ESRC, Swindon

Eaves

2015 "Settling in: Experiences of women on spousal visas in the UK", London: Eaves. http://www.fawce ttsociety.org.uk/wp-content/uploads/2015/06/Settling-In-research-report-9795c1.pdf (accessed 21 November 2017)

Faist, T.

2013 "The mobility turn: a new paradigm for the social sciences?”, Ethnic and Racial Studies, 36(11): 1637-1646. https://doi.org/10.1080/01419870.2013.812229.

Fihel, A., and A. Górny

2013 "To settle or to leave again? Patterns of return migration to Poland during the transition period", Central and Eastern European Migration Review, 2(1): 51-72.

Giddens, A.

1984 "Elements of the theory of structuration". In A. Giddens, The Constitution of Society. Outline of the Theory of Structuration. Polity Press, Cambridge: 1-40

Hoang, L.A.

2011 "Gender identity and agency in migration decision-Making: Evidence from Vietnam", Journal of Ethnic and Migration Studies, 37(9): 1441-1457. https://doi.org/10.1080/1369183X.2011.623618.

Iglicka, $\mathrm{K}$.

2010 Powroty Polaków po 2004 roku. W pętli pułapki migracji. SCHOLAR, Warszawa.

2002 "Poland: between geopolitical shifts and emerging migratory patterns", Population, Space and Place, 8(2): 153-164. https://doi.org/10.1002/ijpg.249.

Irek, M.

2011 "The myth of 'Weak Ties' and the ghost of the Polish peasant: Informal networks of Polish posttransition migrants in the UK and Germany", Working Paper No. 87, Centre on Migration, Policy and Society.

Isański, J., and P. Luczys

2011 Selling One's Favourite Piano to Emigrate, (xi-xxiv). Cambridge Scholars Publishing, Newcastle upon Tyne.

Janta, B.

2013 "Polish migrants' reproductive behaviour in the United Kingdom", Studia Migracyjne - Przeglad Polonijny, 3: 63-96.

Kindler, M., and J. Napierała

2010 "Wstęp", in M. Kindler and J. Napierała (Eds.), Migracje kobiet: przypadek Polski. SCHOLAR, Warszawa: 7-36. 
Klagge, B., and K. Klein-Hitpaß

2007 "High-skilled return migration and knowledge-based economic development in regional perspective. Conceptual considerations and the example of Poland". Centre of Migration Research Working Papers No. 19/77.

Lawthom, R., and C. Kagan

2016 "Feminist composite narratives of Chinese women: the interrelation of work, family and community in forced labour situations", Community, Work \& Family, 19(2): 181-192. https://doi.org/10.1080/ 13668803.2016.1134128.

Łobodzińska, B.

2000 "“Polish Women's gender-segregated education and employment”, [Electronic version]”, Women's Studies International Forum, 23(1): 49-71.

Lutz, H.

2010 "Gender in the migratory process", Journal of Ethnic and Migration Studies, 36(10): 1647-1663. https://doi.org/10.1080/1369183X.2010.489373.

Massey, D.S., et al.

1993 "Theories of International Migration: A review and appraisal", In R. Cohen (Ed.), Theories of Migration (181-216).

Morawska, E.

2001 "“Structuring migration: the case of Polish income-seeking travellers to the West", [Electronic version]Theory and Society, 30(1): 47-80.

Morokvasic, M.

1983 "Women in migration: Beyond the reductionist outlook", In A. Phizacklea (Ed.), One Way Ticket: Migration and Female Labour. Routledge \& Kegan Paul plc, London: 13-32.

Nannestad, P., G.L.H. Svendsen, and G.T. Svendsen

2008 "Bridge over troubled water? Migration, social capital and the welfare state", Journal of Ethnic and Migration Studies, 34(4): 607-631.

Oakley, A.

1972 Sex, Gender \& Society. Maurice Temple Smith, London. Reprinted with new Introduction, London: Gower Publishing Company Limited, 1985.

\section{OECD-UNDESA}

2013 World Migration in Figures. http://www.oecd.org/els/mig/World-Migration-in-Figures.pdf (accessed 27 March 2014

Okólski, M.

2011 Modernizacyjna rola migracji. CMR Working Papers 46(104). Ośrodek Badań nad Migracjami, Warsaw University.

Olsen, W.

2012 "Collecting qualitative data", In W. Olsen, Data Collection. Key Debates and Methods in Social Research, SAGE Publications Ltd, London: 31-92.

ONS

2012 Births in England and Wales by Parents' Country of Birth, 2012. http://www.ons.gov.uk/ons/rel/ vsob1/parents-country-of-birth-england-and-wales/2012/sb-parents-country-of-birth-2012.html (accessed 27 March 2014)

Parutis, V.

2014 “'Economic Migrants’ or 'Middling Transnationals'? East European migrants' experiences of work in the UK", International Migration, 52(1): 36-55.

Pemberton, S., and L. Scullion

2013 "The policies and politics of managed migration: Exploring mature labour migration from Central and Eastern Europe into the UK", Journal of Ethnic and Migration Studies, 1-19. https://doi.org/ 10.1080/1369183x.2013.733863

Pessar, R., and S.J. Mahler

2003 "Transnational migration: Bringing gender in", [Electronic version] International Migration Review, 37(3): 812-846. 
Pollard, N.

2008 Migrants feeling the pull of home?. Institute for Public Policy Research, London.

2008 Floodgates or turnstiles? Post-EU enlargement migration flows to (and from) the UK. Institute for Public Policy Research, London.

Rienzo, C.

2016 "Briefing: migrants in the UK labour market: An overview". The Migration Observatory: University of Oxford. http://www.migrationobservatory.ox.ac.uk/resources/briefings/migrants-in-the-uk-labourmarket-an-overview/ (accessed 27 March 2014)

Ryan, L.

2009 "How women use family networks to facilitate migration: A comparative study of Irish and Polish women in Britain", The History of the Family, 14(2): 217-231. https://doi.org/10.1016/j.hisfam. 2009.02.004.

2009 "Family strategies and transnational migration: Recent Polish migrants in London", Journal of Ethnic and Migration Studies, 35(1): 61-77. https://doi.org/10.1080/13691830802489176.

Scullion, L., and S. Pemberton

2010 Exploring migrant workers motivations for migration and their perceived contributions to the UK: A case study of Liverpool. University of Salford, Salford.

Smith, S.W., A.P. Daunic, and G.G. Taylor

2007 "Treatment fidelity in applied educational research: Expanding the adoption and application of measures to ensure evidence-based Practice", Education and Treatment of Children, 30(4): 121-134.

Snel, E., M. Faber and G. Engbersen

2015 "To stay or return? Explaining return intentions of Central and Eastern European labour migrants", Central and Eastern European Migration Review, 4(2).

Standing, G.

2011 The precariat: The new dangerous class. Bloomsbury, London.

Szewczyk, A.

2012 "New and Old Middle Class Polish Graduates' 'Brain Training' in England”, Studia Migracyjne Przeglad Polonijny, PAN, 3(145): 151-166.

Temple, B.

2011 "Language, identity and integration: findings from research with Polish communities in North West England", ANNALES: Ser.hist.sociol, 21, 307-316.

Trevena, P.

2009 "NNew' Polish migration to the UK: A synthesis of existing evidence”, ESRC Centre for Population Change Working Paper Number 3. http://eprints.soton.ac.uk/72026/ (accessed 21 November 2017).

UKBA

2009 Accession Monitoring: Report May 2004-March 2009. http://webarchive.nationalarchives.gov.uk/ 20100422120657/http:/www.ukba.homeoffice.gov.uk/sitecontent/documents/aboutus/reports/acces sion_monitoring_report/ (accessed 21 November 2017).

UN

2015 United Nations Population Fund - Migration. http://www.unfpa.org/migration (accessed 21 November 2017).

Vertovec, S.

2007 "Superdiversity and its implications", [Electronic version]. Ethnic and Racial Studies, 30(6): 10241054.

White, A.

2014 "Polish return and double return migration", Europe-Asia Studies, 66(1): 25-49. https://doi.org/10. 1080/09668136.2013.855021.

Yeoh, B.S.A., and K. Ramdas

2014 "Gender, migration, mobility and transnationalism", Gender, Place \& Culture: A Journal of Feminist Geography, 21(10): 1197-1213. https://doi.org/10.1080/0966369X.2014.969686.

Zlotnik, H.

2003 The Global Dimensions of Female Migration, Migration Information Source. http://www.mi grationinformation.org/feature/display.cfm?ID=109 (accessed 21 November 2017) 